\title{
"Best Practice" Around 1800. Johann Heinrich Pestalozzi's Educational Enterprise in Switzerland and the Establishment of Private Pestalozzi Schools Abroad
}

\author{
"La mejor práctica" alrededor de 1800. Las \\ iniciativas educacionales de Johann Heinrich \\ Pestalozzi en Suiza y el establecimiento de \\ escuelas privadas Pestalozzi en el exterior
}

"La meilleure pratique " aux environs de 1800. L'entreprise éducative de Johann Heinrich Pestalozzi en Suisse et l'établissement des écoles privées de Pestalozzi à l'étranger

\section{Rebekka Horlacher}

University of Zurich, Switzerland

\section{ABSTRACT}

In the wake of the first PISA-survey, experts in education encouraged educational policy to take the successful Finnish school-system as a model. But the temptation to copy successful attempts in education is even older and leads us back right to the beginning of the heated public discourses about the importance of education in the context of the emerging national states. In the midst of this transnational discourse around 1800 was the Swiss Johann Heinrich Pestalozzi (1746-1827). In his private institutes he tried to apply his pedagogical "method," promising to teach the children the elementary knowledge easily, quickly, and effectively and at the same time to develop these cognitive competencies in harmony with the physical and moral capacities of the young human, leading eventually to a fully developed intelligent moral person. These promises were very attractive for governments, teachers, and parents from all over Europe and even from the United States. 
Key words: Best practice; school reform; history of schooling; Johann Heinrich Pestalozzi; European history.

\section{RESUMEN}

Como consecuencia de los resultados de PISA, expertos en educación han tomado el sistema escolar de Finlandia como modelo de políitica educacional. La tentación de copiar intentos exitosos en educación es bastante antigua y nos lleva históricamente a los agitados debates públicos acerca de la importancia de la educación en el contextos de los emergentes estados nacionales. En el centro de este discurso transnacional estaba el suizo Johann Heinrich Pestalozzi (1746-1827). En sus institutos privados, Pestalozzi trató de aplicar su "método" pedagógico prometiendo enseñar a los niños conocimientos elementales de manera fácil, rápida, y efectiva y al mismo tiempo, desarrollar sus competencias cognitivas en armonía con las capacidades físicas y morales del joven, llegando a convertirla/o eventualmente en una persona moral inteligente plenamente desarrollada. Estas promesas resultaron muy atractivas para los gobiernos, maestros/as, y padres y madres de toda Europa y aún de Estados Unidos.

Descriptores: "La major práctica"; refiorma escolar; historia de la educación y de la enseñanza; Johann Heinrich Pestalozzi; historia europea.

\section{RÉSUMÉ}

Suite à la première enquête PISA, des spécialistes de l'éducation ont encouragé le monde politique à prendre comme modèle à suivre le système scolaire de la Finlande, arrivé en tête de l'étude. La tentation de copier des expériences éducatives couronnées de succès ne date, cependant, pas d'aujourd'hui et remonte, en fait, à la naissance des états nationaux, aux premiers débats violents sur l'importance de l'éducation. Aux environs de 1800, le Suisse Johann Heinrich Pestalozzi (1746-1827) s'est trouvé au centre de ce débat transnational. Dans l'enceinte de ses écoles privées, il a essayé d'appliquer sa " méthode " pédagogique, promettant de transmettre aux enfants les connaissances élémentaires d'une façon facile, rapide et efficace tout en développant les compétences cognitives en parfaite harmonie avec les capacités physiques et morales du jeune être humain, ce qui devait aboutir — finalement — au développement complet de la personnalité sur le plan moral et intellectuel. Ces promesses ont été très attrayantes pour les gouvernements, les enseignants et les parents partout en Europe et même aux Etats-Unis.

Mots clés : mise en application optimisée ; réforme scolaire ; histoire de l'éducation et de I'enseignement ; Johann Heinrich Pestalozzi ; histoire européenne.

$I^{N}$ $\mathrm{N}$ THE WAKE OF THE FIRST PISA-SURVEY, experts in education encouraged educational policy to take the successful Finnish school-system as a model for their own schools, teachers' training and school administration. A representative of this ideology is New York school chancellor Joel Klein who said it would do to find schools about which one could say: "This works. All we've got to do is replicate this." ${ }^{1}$ Although the enthusiasm for Finland (and sometimes Canada, too) seems to have declined in the course of the past few years, Finland is still the virtual "benchmark" of school development or school reform. The idea to leer at foreign models is anything but new - one of the high points of envying other school systems was the Cold War, for instance. But the temptation to copy successful attempts in education is much older and leads us right back to the beginning of the heated public discourses about the importance of education in the context of the emerging national states. In the midst of this transnational discourse around 1800 was the Swiss citizen Johann Heinrich Pestalozzi (1746-1827). 
In 1798, in the course of the Napoleonic wars, the Helvetic Revolution took place. On April 12, 1798, the Helvetic Republic was proclaimed and the new constitution, following the example of the French Revolution, was formally passed. A central government was established, as well as a new penal code which replaced many medieval legal regulations. Also the extension of basic school education was an important issue for the new government, as without education a political participation of the citizens was not possible. For this purpose, the Helvetic government intended to establish a teachers' training institution in Burgdorf, Canton of Bern, with Johann Rudolf Fischer (1772-1800) being appointed its headmaster. The theologist Fischer had been a staff member of the minister in charge of school education, Philipp Albert Stapfer (1766-1840), and while occupying this position he had proven his qualifications for heading the teachers' institution. However, before Fischer could take over his new position, he died suddenly and the Helvetic government had to find a replacement as soon as possible if the teachers' training institution, one of the prestigious projects of the new government, was not to be doomed to become an early failure. In this situation, the government remembered Pestalozzi, who had already shown his sympathies towards political reform in the past and had also supported the new government by way of his publications. Also, as the author of the bestselling novel Lienhard und Gertrud, from the 1780s on he was considered a champion of the disadvantaged class, since one year earlier as the headmaster of an orphanage in Stans, he had already headed an educational project by order of the Helvetic government.

Thus Pestalozzi accepted the position of headmaster of the newly-founded institution which in the course of the following years - at first in Burgdorf, then in Münchenbuchsee and Yverdon - was to become the "Mecca" of school reform and teachers' education based on a newly-discovered pedagogical method.

Whereas initially most parents and political authorities from Switzerland sent their children and future teachers to be educated and trained by Pestalozzi, soon his institute was also known in the neighboring countries and even as far away as in Britain, Eastern Europe and America. Parallel to establishing his educational institution, Pestalozzi had published his ideas and concepts as a book, and under the term "method" these ideas on elementary education soon became an intensely discussed topic of the interested public. Not only had the publications by Pestalozzi himself contributed to this public attention, but so did the ever larger numbers of visitors and the ensuing - mostly positive - descriptions of these visits in magazines and other journals. Ever more governments were sending teachers to Switzerland for training and further training, as they considered this a possible way of finding an answer to the question of how the bulk of the population could be schooled quickly, efficiently, and less expensively and to also make it a productive part of the general modernization of the single nation states.

Stimulated by their experiences and impressions at Pestalozzi's in Switzerland, in the first twenty years of the nineteenth century some of these visitors and temporary teachers opened their own schools in their home countries. Often these schools were very small, and in the beginning they were restricted to quite a small number of students. These schools themselves lasted for different spans of time, but all of 
them had in common that they used the label "Pestalozzi," "Pestalozzean," or "following Pestalozzi's example." To stay successful among the large number of private institutions, referring to Pestalozzi was a possible way to prove success and quality. The descriptor "Pestalozzi" was not only used by the organizations themselves, but relevant literature also assigned it to people or organizations, without stating exactly on what this was based. Popular formulations were, for example, "School following Pestalozzi's example," "using Pestalozzi's method of teaching," or "follower of Pestalozzi's method." With these names it remained unclear in most cases what exactly they meant. In what measure was a school "following Pestalozzi's example" different from any other school not following Pestalozzi's example? What does "using Pestalozzi's method of teaching" mean? Did it mean that, according to the Book of Mothers (Buch der Mütter), one of Pestalozzi's elementary books, students were supposed to loudly repeat in chorus individual letters, then syllables and finally single words? Or that at first there were drawing exercises before students learned how to write individual letters? Or, in other words: How did "best practice" occur at schools being oriented towards the role model of Pestalozzi and his institutions?

I would like to analyze these questions in more detail by way of a case example. For this, I start out from the thesis that organizations are never an identical depiction of any other organization, as contextual factors must also be taken into consideration. Neo-institutionalism calls these contextual factors or societal-cultural expectations; "institutions" which take over an important steering function along with actually organizing organizations. ${ }^{2}$ Consequently, for the relation of model and follow-up organization we may always state a mixture of copy, adaptation, and label. Furthermore, the aspect of the "charismatic leader" must also be taken into consideration, a feature of model organizations which follow-up organizations usually lack. I chose the example of the Pestalozzi Model School (Pestalozzische Musterschule) in Frankfurt, because it is well documented by the sources and thus provides a multi-perspective insight into this school's everyday life and the intentions of the school administration. Through Gottlieb Anton Gruner (1778-1844), headmaster of this model school from 1805 to 1810 , we can also prove a personal connection to Pestalozzi and the Burgdorf institution.

Given the lack of relevant sources from Pestalozzi's own writing, the reconstruction of his institution in Burgdorf is based not only on various official reports, but also on travel reports by visitors giving euphoric or skeptical descriptions of his institution there. On the model school in Frankfurt, we are on the one hand provided with extensive research literature. Apart from this, the invitations to the yearly examinations provide insight into the school's structure and life.

As a first step I will describe the way in which school and teaching were organized in Burgdorf, to give an idea of how the original was organized (1). As a second step I will shortly sketch schooling in Frankfurt as it appears in the context of founding the model school, to show in which environment the model school was situated (2). As a third step I will pursue the question of how far the model school, founded in 1803, changes its topical or organizational nature or its self-perception by taking the additional name of "Pestalozzi Model School" (3). Thus, it is about the question of how 
far the Frankfurt model school was a copy or adaptation of the Burgdorf institute or if simply the label was adopted (4).

\section{Which is the Model? Pestalozzi's Institute in Burgdorf}

The actual reconstruction of Pestalozzi's institute in Burgdorf is somewhat difficult. Although there exist a number of reports by visitors, in most cases they tell about Pestalozzi as a person or about the "spirit of the method," and seldom about the actual way of organizing the school's everyday life or of teaching. However, from the scattered information, teaching at Burgdorf can nevertheless be reconstructed to a certain degree. A telling source in this respect is the report by Adolph Soyaux ${ }^{3}$ who provides quite detailed information about both the "method" and the structure and the organization of teaching at Burgdorf.

According to unanimous statements by the various observers, what makes Pestalozzi's method special is its support for the children's basic powers, which precedes learning how to read, write, and calculate. In this context it is about the clarity of terms and structuring the objects according to a system, which is appropriate to their minds. The development of mind is seen analogously to the development of the laws of physical nature. ${ }^{4}$ That is why elementary teaching, the development of language power, of the power to form, and the power to calculate, is said to be of particular importance. One starts with counting and drawing lines, there follows the first table, on which lines are counted. The teacher says the methodical working of the table for the children first, then each one of the students repeats it. Then there follow the other three tables. With language, at first the vowels, then the consonants are pronounced; when the children know how to handle them they are combined to syllables, and by a third step to complete words. Language teaching develops from letters to words, not only for the native tongue but for French as well, and language teaching is also always combined with object-oriented teaching. ${ }^{5}$ Formal teaching, the $A B C$ of Perception ( $A B C$ der Anschauung), is meant to teach how to understand and draw the basic terms and figures of geometry. Also there, the teacher says first, then the students copy. ${ }^{6}$ Furthermore, the slate is used, and in this way the pupils are already able to practice drawing and writing before knowing how to work with quill and paper.

If we further follow Soyaux's description (who visited Burgdorf in August, 1802) the institution consists of 102 people, seventy-two of whom are students and about ten are teachers, the remaining inhabitants of the institute may be supposed to have been servants and maids. There are also always some guests who have come to learn about the method. ${ }^{7}$

Usually, students are between five and thirteen years old, but most of them are between seven and nine, which is appropriate to the real purpose of the institute, elementary teaching. The social origin is called "middle class." The children come from almost all Swiss cantons, in the context of which the short distance to Bern is considered to be particularly advantageous because it is there where many of the representatives live with their families and sons of school age. "Because of this, soon the institution was populated with students from all the regions of Switzerland; the thus 
resulting mixture in respect of origin, fate, character, talents could not be greater, and not without astonishment one observed how all these differences were melting into one mould so easily, which proves that it was suitable for all of them, as it was the mould of nature." ${ }^{8}$ There are no fixed classes but learning groups for certain teaching units which are again and again newly structured because students learn their subjects at different, individually set, performance levels.

The day begins at six o'clock in the morning; at ten o'clock in the evening all come together again for "the father's moral inspection." 9 The bathing site on the River Emme is much frequented and during the leisure hours in the evening there is marching up and down. Visitors also report that the children make a healthy impression: "Separated from the rest of the world, kept in constant activity, and always with teachers at their sides, they are left to childlike innocence and their natural brightness. Their daily activities have so much seized their minds that they do not think about anything else than — drawing and arithmetic. Even on Sundays they met voluntarily in the teachers' rooms and, single or in groups, did arithmetic exercises. How often did I listen to boys who busily recited the tables for themselves." ${ }^{10}$ Disciplinary problems are unknown; teachers and students live in harmony. On the whole, Soyaux considers learning a game, not a "serious effort of mind." 11

Thus, the organizational cornerstones of the model have been given. What makes Burgdorf special, is its support of the children's basic powers, that teaching happens by level groups, and the didactics assume that mind and nature develop analogously. Derived from this is the importance of elementary teaching with its elements of language, figure, and number. The teacher-student relationship is qualitatively and quantitatively good, geographically the students come from all over Switzerland, randomly rather than from wealthy families, and the true elite is only marginally represented. Into which context, now, shall this model be integrated?

\section{Schooling in Frankfurt at about 1800 and the Founding of the Model School}

In about 1800, schooling in Frankfurt is typical for the age. Grammar school is organized as a scholarly school, which finds it difficult to open up towards the new sciences and modern languages, which again is criticized by the citizens of Frankfurt. Most of them are in the trading business, as are the parents of the school children. Elementary school_-also called quarter school-offers traditional, catechismoriented teaching. School is Lutheran, the denominational minorities also living in Frankfurt - Catholics and Jews - have their own, private schooling. Calvinist Reformed schools however, are banned. The wealthy Frankfurt families criticize the elementary or quarter schools "for their restricted teaching program and the high share of students from lower class families." In compensation they establish extended private schooling as well as a tradition of private tutors. ${ }^{12}$

In 1790, Friedrich Maximilian von Günderrode (1753-1824) becomes chairman of the Consistorium, Frankfurt's political board. Shortly after his assumption of office he appoints Wilhelm Heinrich Hufnagel (1754-1830) Senior of the Lutheran 
clergy. Both support a reform of schooling. One important issue in this context is the "nationalization" of education, because it is putting an end to denominational supervision, which, however, happens only slowly. ${ }^{13}$ In 1800 , the Freemasons Lodge "Unity" (Zur Einigkeit) interferes with the debate and intends to found a modern school from fund-raising among the citizens, and out of which there develops the model school. This private school, funded by a foundation, provides a new way for the City of Frankfurt's denominational and political leadership to realize its own school reform, which has been blocked for several reasons. ${ }^{14}$ The idea is to employ the model school as the core and example of school reform. The program of this citizens' school has been lost, but from preserved excerpts we know that topically not only vocational training was offered but also cross-denominational religious education and factual subjects. Also, the support of an attitude of honour and community was in the forefront. It is about a kind of general education independent of the students' origins, followed by vocation-oriented education.

In May 1804, the model school is renamed as "Pestalozzi Model School." This renaming, which may be understood to express the teachers' attitude, is closely connected to Gottlieb Anton Gruner, ${ }^{15}$ a teacher in Heilbronn, who in the autumn of 1803 had stayed with Pestalozzi in Burgdorf. He is asked by the teachers of the model school to inform them about Pestalozzi's teaching method. Five years later, Gruner describes this as follows: "The teachers of the then just starting model school asked me to inform them about Pestalozzi's invention, as I had just returned from studying it." 16 We do not know anything about the teachers' reactions, but we must assume that they were convinced by what they heard, as Gruner becomes the new headmaster.

Although funded by a foundation, the school depends on meeting the parents' demands in respect of their children's school education. This is already bemoaned by Gruner soon after his assumption of office (for example in four printed letters from 1806 to the close collaborator of Pestalozzi's, Johannes Niederer). ${ }^{17}$ Gruner resigns in 1810 . The reasons remain unclear, but it is possible that his high ethical demands could not be met and that he intended a school on which the parents would not have that much influence. ${ }^{18}$ In 1812 the history of the model school comes to an end in the sense that it is renamed a junior high school (Realschule). The reason is the law regarding schools of the Grand Duchy of Frankfurt, newly-founded in the context of the Napoleonic reforms. A mostly state-financed educational system is established, and supervision by the clergy is further restricted. ${ }^{19}$ In this way also schooling is differentiated, the model school is increasingly rebuilt into a vocational school. With Napoleonic rule coming to its end, the Grand Duchy of Frankfurt is dissolved and the Imperial City is legally re-established. Many Napoleonic laws are lifted, including the 1812 law on schools. Those schools, however, as having older roots, such as the model school, remain, and school supervision is again given to the clerical authorities.

\section{Organization of the Model School}

The first year of the model school is badly documented by the sources, as the files have not been preserved. But we know, that under the first headmaster of the model 
school, there are lessons every morning from seven o'clock to ten o'clock and in the afternoon of four days from two o'clock to four o' clock. The subjects of spelling, reading, arithmetic, writing, Christian religious education, natural sciences, and geography are taught as well as memory practices. ${ }^{20}$ Both girls and boys attend school; classes are structured according to performance levels. ${ }^{21}$ With Anton Gruner becoming headmaster, the timetable is not fundamentally changed, but he introduces weekly conferences - they happen on Saturdays from seven o'clock to eight o' clock - to make joint work by the teachers of the school possible. ${ }^{22}$ The distribution of students among different performance levels remains. This way of organizing teaching is indeed the same as in Burgdorf, but for Frankfurt it is nothing new. ${ }^{23}$

Girls have a topically reduced workload. They are not taught geometry and commercial arithmetic but household skills instead. From 1807 there are also female teachers. Every week there is a public examination for parents and other interested people. Apart from the usual examinations, drawings and test writings are also exhibited. $^{24}$

The self-descriptions, each of which being written by Gruner and added to the invitations to the yearly, great, public examination, provide more detailed insights into organizational matters. Gruner writes the first self-description even before his assumption of office, thus this writing may be interpreted as a programmatic writing or declaration of intent. It is the task of the model school, it says, "to support civil virtues and civil welfare." ${ }^{25}$ With this goal in mind, Gruner makes suggestions on the following fields: "topics of lessons," "method," and "organization of school by way of an appropriate structure of classes, by way of fixing the structure of the day, by way of school discipline." Supporting civil virtues and civil welfare, it says, are primarily "the development and foundation of the moral-religious mind leading towards true welfare [...] Thus, what is essential is most of all the teaching of religion and morals." 26 This goal, Gruner writes, will be achieved most of all by way of supporting and developing the various powers: Gruner explicitly speaks of "the power of will" and "the power of thinking." 27 Specifically, this means: "Exercises on perception and language." 28

Given the demands of life, he says, civil teaching is an important point, however one should take care not to neglect the "inner power" in this context. Further listed are: natural sciences, natural history, history, and description of the earth (always focused on "close" objects). It is discussed if there should be French lessons, but the issue is not decided; this language, it is said, might as well be a matter of private tutoring. ${ }^{29}$

Another category for Gruner, which shall not be neglected, is the "skills of spiritual and physical activity." Among them he counts writing and reading, for girls also "female works," and "physical exercises." Also, aesthetics should not be forgotten, which are closely connected to ethics. Here, aesthetics mean expressive reading, good handwriting, drawing, and singing. ${ }^{30}$

How, now, are these subjects to be taught? Religious education and virtues are supposed to touch the heart, closeness to life shall be preferred to examples. ${ }^{31}$ The teaching of history also serves the teaching of morals and practicing a civil attitude. ${ }^{32}$ Gruner also comments on the question of how far the model school follows the 
example of Burgdorf. In this context he emphasizes the significance of the "Pestalozzi spirit," the latter he believes to be realized by preferring emotions to intellect. At first, he states, the child's emotions must be addressed, the correct basic attitude must be created; only then mind and reason shall be addressed. ${ }^{33}$ Thus, Gruner presents his Frankfurt school as a school which indeed strives for copying the example as perfectly as possible, but which does not see this closeness in organizational similarity but in the "spirit," which has to be as similar as possible.

For the teaching of languages Gruner suggests two methods, Pestalozzi's and Pöhlmann's. ${ }^{34}$ In this context, Pöhlmann is the model for concrete, practical-methodical work; ${ }^{35}$ Pestalozzi for the spiritual-ideal dimension. For writing, copperplate is used. ${ }^{36}$ For calculating Köhlein's ${ }^{37}$ Tables $^{38}$ — here it seems as if Gruner looks for the teaching aid, which is most suitable for each subject. The school is organized by "classes." ${ }^{39}$ Teaching happens by four demand levels, beginners - Class 4 - learn with the help of Pestalozzi's method books (Buch der Mütter, ${ }^{40}$ Pestalozzische Übungen der Zahlenverhältnisse, ${ }^{41}$ Elementarvorübungen zum Zeichnen und Schreiben nach Pestalozzi $\left.{ }^{42}\right) .{ }^{43}$

One year later, in the first invitation to the public examination under Gruner as headmaster, topically the same is said, but formally it is rather formulated as an advertisement for the school. ${ }^{44}$ As a methodical reference, for example, only Pestalozzi's name appears, other names are missing. The program and the concept of teaching, however, are identical with Gruner's first writing. ${ }^{45}$

One year later again, Gruner tells about a fast-growing school. At the same time, however, he points out that although fast growth is a pleasant thing it is a problem for the organization of the institution because it is difficult to find suitable teachers. ${ }^{46}$ Implicitly, there is also some first criticism. Obviously, the public opinion was not always convinced that the new teaching method would indeed achieve the desired result. ${ }^{47}$ Gruner meets this objection by arguing that the true success of Pestalozzi's method would become really obvious if he himself taught the students right from the beginning.

Gruner himself calls the efforts in Frankfurt "unfortunately weak attempts." $48 \mathrm{He}$ assumes that the method could not only be partly introduced at a school but that there must be an either-or decision for or against the method, the true problem being to find enough parents for such a school. Parents are needed, he says, who do not judge on the quality of a school according to quick learning success but are interested in elementary education. For Gruner (and thus also for the method), he says, it is important that the children's "breath to learn" is not spoiled and that there is no leaving the "path of nature." 49

For Gruner, actual work also shows that furthermore a "Pestalozzi school" will only work if it is preceded by a "family education according to Pestalozzi." Also in Burgdorf it had become obvious that the method worked best with the youngest and also the parents were most ready for it at that age. From this they concluded "that we must prepare the people for the cure of the method before we may force it on them." ${ }^{50}$ Thus, Gruner suggests a division of work: Pestalozzi and his staff members in Yverdon, where Pestalozzi has moved in the meantime, shall further develop the 
method; Gruner will take care of how it could be implemented for a broad population. ${ }^{51}$ For implementation he counts on the mothers; this completely according to Pestalozzi's explanations. They are supposed to be the disseminators of the method and to prepare the children for the method at school. ${ }^{52}$

This judgment is supported again in the report from 1809. The elementary method, it says, has been completed. This had partly happened by way of an exchange with Yverdon, partly also based on his own "inventions": "As it is a matter of course without further mentioning, the basic principles of our way of teaching have stayed the same, but what concerns their implementation we have learned from Yverdon how to implement some of it which has not been known to the greater public, partly our elementary teachers have themselves found out about some (elementary) ways of teaching which are increasingly proving their worth." 53

\section{Conclusion}

Thus, again it becomes obvious that the question about the model-copy relationship cannot be answered at the organizational level. "Best practice" cannot be reduced to the formal level but refers to a "spirit" which determines and characterizes actual work and depends fundamentally on a charismatic leader or an appropriate leadership team.

In this way, to a certain degree, the question can also be answered as to whether the model school in Frankfurt was a copy or adaptation of Burgdorf or if simply the label was used for advertising purposes. For the first five years, on which I have focused here, probably some of each is true. On the one hand, there was the attempt to introduce "elementary education" to which, apart from generally developing the powers, clearly moral-educational elements were connected. This part of the model school may count as a copy.

Methodically, Pestalozzi's method was also employed, as shown by Gruner's first programmatic writing, however not exclusively. There were a variety of offers of methodical writings and textbooks, which were definitely used, not least because they were according to the needs of teaching practice but did not compete with Pestalozzi's doctrine. Actual teaching may rather be called an adaptation-one tried to come as close to the model as possible without being dogmatic.

The actual organization of the school, however, may be supposed to have been most different from Burgdorf, or in other words: as far as the organization of the school can be reconstructed, we find many parallels to Burgdorf, but these are also found at other schools which were considered "modern," and thus they cannot be traced back to a "Burgdorf influence" in a way which would be methodically correct. Rather, organizational parallels can be explained by a general effect of the grammar of schooling. ${ }^{54}$ There exists a practical or suitable way of organizing school under comparable contextual conditions which pushes through. In this sense, we might find the label aspect, in the sense of supporting sales in a highly competitive market of basic school education.

Thus, the Frankfurt model school is a mixture of copy, adaptation, and label, in 
the context of which the label must be understood to provide the identification potential. The latter is supposed to convince parents to send their children specifically to this school, but also it is meant to motivate the teachers to apply for positions specifically at this school. If this label is missing, probably a follow-up organization will soon change into quite an ordinary organization, which — in respect of school as an organization - is different from other schools in the vicinity by some details at best.

In this sense, for the concept of "best practice" sobering conclusions must be drawn. Orientating at a model may indeed stimulate one's own work, and observing other models may also definitely extend one's own repertoire or the idea of how school and teaching may be organized and done. However, the hope of most of education politicians and educational experts that by way of the "best practice" concept weaknesses of one's own way of organizing school and teaching could be overcome comparatively easily must be called rather naive. Schools, teachers and classes serving as a model for a "best practice" concept are based on a variety of cultural, historic, and social contextual conditions which can never be imitated. Thus, however, the decisive basis for this model also being successful in other contexts is also lacking. But it seems as if this insight comes only slowly to education politicians and educational experts in charge, ${ }^{55}$ obviously the temptation of finally having found a possibility to further develop one's own educational system by way of the "best practice" concept in such a way that in the course of the next PISA study the desired results will be achieved is too big. But the historic example has demonstrated that obviously the reform and development of schools is a much more complex enterprise than education politicians and education experts believe. If it is possible at all to further develop schools in the sense of the more recent school development concepts however, is something, which shall not be discussed here. But it seems to have become obvious by this historic example that more simple models of steering and governance cannot serve as a theoretical foundation of school development and school reform. Too powerful are contextual factors which cannot be influenced but at best be historically cleared and thus understood. Thus, the ideology behind the sentence "This works. All we've got to do is replicate it" is simply naive and rather an obstacle than a support for school development. This is remarkably well expressed by history — it is only that now and then we should ask it before propagating remedies.

\section{Notes}

1. Klein, 2008.

2. Meyer \& Rowan, 1977.

3. Ferdinand Adolph Soyaux (1773-1823) was a reverend in Berlin, and in 1802 he visited Pestalozzi's institution in Burgdorf. On it, he wrote a report under the title Pestalozzi, seine Lehrart und seine Anstalt (1803). Literature on Pestalozzi counts Soyaux and his report among the critics, as he not only praises Pestalozzi and his method.

4. Soyaux, 1803, 19. 
5. Ibid., 87.

6. Ibid., 86.

7. Ibid., 82 .

8. Ith, 1802,89 , freely translated.

9. Soyaux, $1803,88$.

10. Ibid., 89 , freely translated.

11. Ibid., 93.

12. Picard, 2003, 20, freely translated.

13. Ibid., 21.

14. Ibid., 22.

15. Gottlieb Anton Gruner (1778-1844) is considered one of the first supporters of Pestalozzi's pedagogy in Germany. From 1797 to 1800 he studied theology, history and philosophy at Göttingen and Jena. Then in Copenhagen he accepted the post of Erich von Bernstorff's (1791-1837) private tutor. In a courtly world of adults, attempts at educating were threatened with becoming a failure. Thus, in 1803 he took the boy to Salzmann's institute. At the beginning of October 1803, he visited Pestalozzi in Burgdorf. Initially skeptical towards method and principles of education, later he called Burgdorf his "third university" (Schmidt 1928, 31). After his return to Germany, he published in 1804 the book Letters from Burgdorf (Briefe aus Burgdorf), which found public recognition. In 1805 he married Lotte Lutz (1776-1832). From 1805 to 1810 Gruner was the headmaster of the "Model School" in Frankfurt on the Main. From 1812 to 1817 he taught at the grammar school in Coburg, then until retiring he was the headmaster of the seminary in Idstein.

16. Gruner, 1809, 16, freely translated.

17. Gruner, 1806b.

18. Picard, 2003, 27.

19. Ibid., 28.

20. Froning, 1903, 41.

21. Ibid., 44.

22. Ibid., 52.

23. Ibid., 57.

24. Ibid., 59.

25. Gruner, 1805, 22.

26. Ibid. 23, freely translated.

27. Ibid., 24.

28. Ibid., 25.

29. Ibid., 28.

30. Ibid., 29.

31. Ibid., 31.

32. This attitude is based on the knowledge that humans have never fared better than at present. (ibid., 32).

33. Ibid., 33. 
34. Johann Paul Pöhlmann (1760-1848), the headmaster of a successful private teaching institution, later the headmaster of the City Realschule in Erlangen and the author of a number of textbooks and children's books, describes in Ein Mittel zur Zeitersparniss beym Corrigiren dictirter Aufä̈tze und zu Erreichung verschiedener anderer Zwecke (1804, $1805,1808)$ a new method of teaching orthography which is supposed to relieve the teacher's burden but is nevertheless educationally thought out. Pöhlmann's way of teaching is presented by conversations between teacher and children. In 1787 Hufnagel comments positively on Pöhlmann's private school in Erlangen (Hufnagel 1791); in 1788 the latter is also made an honorary doctor of the University of Erlangen for his educational achievements (Lang, 1994, 252). In 1805 his private institution is changed into a Royal Prussian Realschule for Boys. In parallel, the private institution continued as a girl's school, and a pedagogical seminary is also included into the Realschule. With the school being changed into a state school, its decline begins. There are a variety of reasons. On the one hand, it seems as if in respect to organization Pöhlmann came to his limits, on the other hand in the course of the extension many new teachers joined whose quality was not always as expected (ibid., 255). In 1818 he left Erlangen for reasons of health and moved to Ostheim as a reverend (ibid., 251).

35. Gruner, 1805, 38.

36. This means a kind of cursive writing, which is based on Latin writing, not on gothic handwriting.

37. Johann Friedrich Köhlein (1774-1809) originated from Homburg, where his father was a teacher at a girl's school. His contact with Wilhelm Friedrich Hufnagel helped him to a position as a teacher at the orphanage in Frankfurt. Also, the administration of the orphanage allowed him to teach one lesson at the Model School. He published arithmetic tables, which were suitable for children of the most different knowledge levels (dates according to Gruner, 1809).

38. Johann Friedrich Köhlein: 128 Rechentafeln für Stadt- und Landschulen und zum Privatunterrichte. Frankfurt am Main: Mohr und Zimmer 1803.

39. Gruner, 1805, 41. Students are taught together until the age of nine, which was also due to having not enough girl students for separated classes.

40. Johann Heinrich Pestalozzi: Buch der Mütter, oder Anleitung für Mütter, ihre Kinder bemerken und reden zu lehren. Zürich: Gessner 1803.

41. Johann Heinrich Pestalozzi: Anschauungslehre der Zahlenverhältnisse. Zürich: Gessner 1803/1804.

42. Here it may be supposed that one worked with one's own teaching aids, as the appropriate elementary book was only published in 1809 (Joseph Schmid: Die Elemente des Zeichnens nach Pestalozzischen Grundsätzen. Bern 1809).

43. Gruner, 1805, $44 f$.

44. Gruner, 1806a.

45. Gruner, 1805.

46. Gruner, 1808, 9.

47. As in Burgdorf, also in Frankfurt it was criticized that "at this school the children learn little or nothing at all” (Gruner, 1808, 17, freely translated). Gruner does not deny that such children exist, but he wants to point out why these children learn nothing or less than they are capable of (ibid., 18). On the one hand, he says, this is due to children being lazy or badly educated. Thus, as Gruner argues, they were not really ready to learn. The other reason is that from the outside exaggerated demands are placed on the speed of learning. This, he says, is impossible at a school such as the Model School, as there the concept of 
"comprehensiveness" plays a role. Gruner himself does not use this term, but he speaks of fast-learning success being impossible at a public school if a kind of "teaching which nourishes both heart and mind" (ibid., 21) shall not be affected. Thus, for Gruner there is the question if a "mechanical way of calculating" should be preferred to "dealing with the relation of numbers" (ibid., freely translated).

48. Gruner, 1806b, 6.

49. Ibid., 21.

50. Ibid., 35, freely translated.

51. Ibid., 36.

52. Ibid., 38.

53. Gruner, 1809, 36. To give evidence, Gruner gives some examples: "Our singing teacher, Mr. Carl, has found that Pestalozzi's way of singing instruction is very practicable for bigger classes, and has introduced it with much success, which was to be expected. Mr. Nänny, by information from Yverdon, has traced down the elementary teaching of the doctrine of geometric sizes much better than before, and has connected the doctrine of aesthetic figures to it. Mr. Wetzel has paved his own way with writing in elementary teaching, which will hardly go wrong, and Mr. Nänny has even improved his reading method, which becomes also obvious by the progress of the children" (Ibid., 37, freely translated).

54. Tyack \& Tobin, 1994.

55. Overesch, 2007.

\section{References}

Froning, R. (1903). Geschichte der Musterschule. In Musterschule (Ed.) Festschrift zur Hundertjahrfeier der Musterschule (Musterschule —Elisabethenschule) in Frankfurt am Main 1803-1903 (pp. 35-156). Frankfurt am Main: Diesterweg.

Gruner, G. A. (1805). Kurzgefasstes Resultat meines Nachdenkens über die Einrichtung einer guten Bürgerschule. Frankfurt am Main: Varrentrapp und Wenner.

Gruner, G. A. (1806a). Beschreibung des gegenwärtigen Zustandes der hiesigen Musterschule mit Bemerkung dessen, was ihr noch zu wünschen ist. Eine Einladungsschrift zu der auf den 8ten, 9ten und 10ten December festgesetzten öffentlichen Prüfung in dieser Anstalt. Frankfurt am Main: Bayrhoffer.

Gruner, G. A. (1806b). Noch ein Wort zur Empfehlung der kräftigeren namentlich der Pestalozzischen Weise in der Behandlung und im Unterrichte der Jugend. Mit Hinsicht auf die Hindernisse, welche ihr in Lehranstalten und Schulen entgegenstehn. Ein Nachtrag der Erfahrung zu den Briefen aus Burgdorf. Frankfurt am Main: Mohr.

Gruner, G. A. (1808). Nachtrag zu der in der Einladungsschrift zu der letzten öffentlichen Prüfung gegebenen Beschreibung der Musterschule, samt einer Beantwortung der Frage: in wie ferne diese Anstalt bisher ihrem Zwecke entsprochen habe, jetzt entspreche und künftig entsprechen werde. Eine Einladungsschrift zu der auf den 20., 21., 22., 23., 24sten Junius festgesetzten öffentlichen Prüfung in dieser Anstalt. Frankfurt am Main: Mohr.

Gruner, G. A. (1809). Johann Friedrich Köhlein's, Lehrers an der Musterschule Leben, Character und Verdienste. Eine Einladungsschrift zu der auf den 26. 27. 28. 29. und 30ten Junius festgesetzten öffentlichen Prüfung in der Musterschule. Frankfurt am Main: Mohr

Hufnagel, F. (1791). Viel Gutes im Stillen. Eine Nachricht für Eltern und Kinderfreunde. In F. Hufnagel (Ed.) Liturgische Blätter, Band 1 und 2. Erlangen: Palm.

Ith, J. S. (1802). Amtlicher Bericht über die Pestalozzische Anstalt und die neue Lehrart derselben. Bern: Gessner. 
Klein, J. (2008). How many billionaires does it take to fix a school system? The New York Times, March 9, 2008. [On-line], Available: http://www.nytimes.com/2008/03/09/ magazine/09roundtable-t.html?_r=18pagewanted=2 [12/22/2009]

Lang, G. (1994). „Wähle, empfinde, überdenke und geniesse.“ Das Stammbuch des Erlanger Pädagogen Johann Paul Pöhlmann. Erlanger Bausteine zur fränkischen Heimatforschung, 42, 247-324.

Meyer, J. W. \& Rowan, B. (1977). Institutionalized organizations: Formal structure as myth and ceremony. The American Journal of Sociology, 83(2), 340-363.

Overesch, A. (2007). Wie die Schulpolitik ihre Probleme (nicht) löst. Deutschland und Finnland im Vergleich. Münster: Waxmann.

Picard, T. (2003). „Bürger-Kapital für Bürger-Erziehung“—Die Gründung der Musterschule und ihr erstes Jahrzehnt 1803-1813. In D. Kallus Musterschule 1803-2003. Festschrift zum 200jährigen Bestehen des Gymnasiums in Frankfurt am Main (pp. 18-30). Frankfurt am Main: Diesterweg.

Schmidt, E. (1928). Gottlieb Anton Gruner. Ein deutscher Schulmann und Volkserzieher aus der Zeit der Pestalozzischen Bewegung. Frankfurt am Main: Verlag des Lehrervereins.

Soyaux, F. A. W. R. (1803). Pestalozzi, seine Lehrart und seine Anstalt. Leipzig: Fleischer.

Tyack, D. \& Tobin, W. (1994). The "grammar" of schooling: Why has it been so hard to change? American Educational Research Journal, 31(3), 453-479. 